\title{
MID-TERM ASSESSMENT OF THE ACTIVTIES OF FADAMA III DEVELOPMENT PROJECT IN CROSS RIVER STATE
}

\author{
J. B. EFFIONG AND A. B. ASIKONG
}

(Received 14 September 2012; Revision Accepted 7 November 2012)

\begin{abstract}
This paper assessed the activities of Fadama III project in Cross River State. It viewed the aim, objectives, achievements, perceptions of beneficiaries and challenges of the project in the state. It was discovered that Fadama III is aimed at increasing the income of rural land and water resource users, reduce rural poverty, increase employment opportunities and facilitate rural economic development. The project drew funds for agricultural and nonagricultural enterprises, including infrastructural development and recorded appreciable achievements at mid-term in infrastructural construction, enterprise funding and training of participants. Consequently, beneficiaries expressed satisfaction over the benefits they derived from the project. The challenges of Fadama III in Cross River include, among others, delayed beneficiaries contribution and inadequate funds to handle requests from communities. The project has thrived in Cross River State, despite various challenges. This study therefore suggests that all stake holders should pay their financial contributions on time, monitoring and supervision should be intensified and there should be intensification of stake holders' sensitization.
\end{abstract}

KEY WORDS: Mid-term, Assessment, Fadama III, Development Project, Cross River State

\section{INTRODUCTION}

Fadama is a World Bank assisted project, designed to meet the challenges of the Nigerian agricultural sector. The project is executed in phases, implying that Fadam III in Cross River State, is built on the foundation of Fadama I and II, even though Cross River only participated in Fadama I and did not take part in Fadama II (Elemi 2011).

The word 'Fadama' is a Hausa name for irrigable land, usually low-lying plains under-lay by shallow aquifers, found along Nigeria's major river systems. Such lands are usually fertile, suitable for irrigated production, fishing and provide feed and water for livestock (Simonyan et al 2011). Fadama is an area of land, with shallow water table which allows it to be flooded during the rainy season and moist during most part of the dry season. Soils in areas such as the Fadama land are usually rich in organic matter and other nutrients which make them suitable for growing crops. The characteristics of shallow water table made it possible for shallow wells to be dug in such areas to get water during the season for irrigation and several other uses. This served the main objective of the first phase of the Fadama development project which was implemented in few northern states and Cross River. The inability of Fadama I to serve competing users of the resource, brought conflict between crop farmers and herdsmen, this led to the expansion of the project's scope to form Fadama II, in which Cross River did not participate because of the state government's inability to pay counterpart funding (Maisamari, 2007). The discovery of the Fadama project, as a viable tool for responding to the challenges of the agricultural sector, led to the termination of Fadama II, in order for Fadama III to take off, where the project's scope became national. Fadama III is known as an integrated agricultural and rural development project that is designed to deliver financial and technical resources directly to beneficiary groups (Angba, 2011). Fadama III has a bottom - top development approach, with emphasis on stake holders participation, especially at community level (Elemi, 2011).

The project was designed to benefit the following groups;

a. Rural poor engaged in economic activities, including farmers, fishermen, traders and hunters among other.

b. The disadvantaged (widows, sick, HIV infected persons and other vulnerable groups).

c. Service providers, including government agencies and private operators among others.

Private economic agents who legitimately share resources in the project zone were included as beneficiaries to ensure that;

i. Conflicts arising from resource access, were acknowledged and addressed.

ii. Participatory implementation mechanisms, needed to manage the land resource at larger

J. B. Effiong, Department of Agricultural Economics and Extension, Faculty of Agriculture, Forestry and Wildlife Resource Management, University of Calabar, Calabar, Cross River State, Nigeria

A. B. Asikong, Department of Agricultural Economics and Extension, Faculty of Agriculture, Forestry and Wildlife Resource Management, University of Calabar, Calabar, Cross River State, Nigeria 
scale than plot in a sustainable manner were in place (Agom, 2011).

Fadama III was designed to be implemented in 20 Local Government Areas (LGAs) per state. If a state has 20 or less Local Government Areas, the project operates in all the Local Government Areas. Thus in Cross River State the project is seen in all the 18 LGAs in the state (Agom, 2011).

i. Sensitization and mobilization by facilitators and state Fadama coordination office. ii. Formation of economic interest groups (Fadama user groups and Fadama Community Associations).

iii. Opening of bank account.

iv. Project rural appraisal (PRA)

v. Preparation of local development plan (L.D.P)

vi. Preparation of sub-project proposal.

vii. Disbursement of funds in trenches.

The project supported both agricultural and nonagricultural enterprises in Cross River State (Elemi, 2011).

In line with the participatory process of the project, it is jointly funded as shown in table 1.

Table1: Project funding

\begin{tabular}{ll}
\hline Stakeholders & $\begin{array}{l}\text { Financial contribution in } \\
\text { Dollars (\$) }\end{array}$ \\
\hline World bank & \\
Federal government of Nigeria & $250 \mathrm{~m}$ \\
State government & $23 \mathrm{~m}$ \\
Local government areas & $77 \mathrm{~m}$ \\
Communities & $40 \mathrm{~m}$ \\
Total & $60 \mathrm{~m}$ \\
\hline
\end{tabular}

SOURCE: Adapted from community implementation manual of Fadama III, Cross River Fadama coordination office.

Cross River State contributes N56.5m annually for five years, while the 18 local government areas contributes N20m annually.

\section{Objectives of study}

The broad objective of this study is to assess the activities of Fadama III in Cross River State.

The specific objectives include to:

i. identify the aim and objectives of Fadama III project.

ii. identify the achievements of the project in Cross River State.

iii. assess the perception of Cross River State beneficiaries about Fadama III.

iv. identify the challenges of the project in Cross River State.

v. make relevant recommendations.

\section{Concept of Fadama III}

The concept of Fadama III was brought about by the need for government to fight the challenges of her economy and curb pervasive poverty in rural areas, thereby restoring the agricultural sector to its position in the economy. (National Agricultural Investment Plan, 2010). The persistent poverty level in rural areas is seen as a reflection of the poor performance of the agricultural sector, because it is mostly operated by rural subsistent farmer (Fadama III project Appraisal Document, 2008). The dominance of the oil sector also masked the impact of the agricultural sector on the nation's economy, and was particularly responsible for the decline in its share of value added in GDP over the years, (NAIP, 2010).

The Nigerian country report (2007), as reviewed by the World Bank held that the oil sector contributed 52 percent of GDP in 2005, oil and gas gave 99 percent of export and provided 85 percent of government revenues, but contributed only 4 percent to employment. On the other hand, four-fifth of the 8.3 percent growth in the economy, outside oil in 2005, came from agriculture. Thus it became clear that agriculture is the back bone of the Nigerian economy (Project Appraisal Document, 2008).

Consequent upon the identification of the agricultural sector by government and policy makers as having the high potential for growth of the economy, a key to achieving poverty alleviation, food security and the Millennium Development Goals (MDGs), the Federal Government of Nigeria and its policy makers came up with a Country Partnership Strategy (CPS) to change the situation (Chudi, 2007).

It was on this note, the third phase of the Fadama development project (Fadama III) was conceived among other initiatives embedded in the Seven Point Agenda (SPA) of 2007.

The word 'Fadama' was adopted in the design of the World Bank assisted project to Nigeria which was known as Fadama I (Nkoya et al, 2008).

Studies by Akinlade et al (2008), reveals that Fadama I was launched in 1992 and implemented in few 
northern states, while Fadama II was launched in 2004 and covered 18 states. Cross River State took part in the first phase of the project (Fadama I) as a facility state (though short lived) and is thus referred to as Fadama III in non-Fadama II states (Ele, 2011). According to Angba (2011), Fadama I had a top-bottom development approach and focused on irrigation with the support of the World Bank, while Fadama II expended its scope through a combination of World Bank and African Development Bank (ADB) support to cover areas outside irrigation. It implemented an innovative Local Development Planning (LDP) tool, and built on the success of Community Driven Development (CDD) mechanism (Adeniyi, 2007).

Fadama III was approved by the World Bank's Board of Executive Directors on July, $1^{\text {st }} 2008$, but became disbursement effective on $23^{\text {rd }}$ March, 2009. The project has a life span of 5 years $\left(23^{\text {rd }}\right.$ March, 2009 to $31^{\text {st }}$ December, 2013). In Cross River, Fadama III was officially launched on the $26^{\text {th }}$ of November, 2009 (Angba, 2011).

\section{Aim and Objectives of Fadama III}

The third phase of Fadama project was conceived against various challenges facing agriculture, such as highly degraded land, rising cost of labour in rural areas, rural underdevelopment leading to massive rural - urban migration, absence of feeder roads to evacuate agricultural produce, poor access to productive inputs for crops, livestock and fish production etc (Agom, 2011).

The project development objective of Fadama III, is to increase the incomes of rural land and water resource users on a sustainable basis.

Fadama IIl's strategic objectives include to;

i. enhance growth in sectors other than oil in order to achieve increased food security.

ii. reduce poverty and create employment in rural areas and

iii. increase opportunities for rural economic development.

The project aimed to achieve these objectives through 5 major components;

i. Institutional and social development

ii. Physical infrastructure

iii. Transfer and adoption of technology to expand productivity, improve value added and conserve land quality.

iv. Support extension and applied research.

v. Provide matching grants to access assets for livelihood improvement (Adeniyi, 2007).

Project planning and implementation: The beneficiaries of this project in Cross River State exist within various cooperative groups, with each group managing a specific enterprise. Thus taking part requires being identified in a group of 20 members (Fadama user group) who will identify an enterprise, they wished the project to support. The Fadama users groups were in turn facilitated to form Fadama Community Associations (FCAs), each of which is an apex organization of 15 FUGs at community level. The FCAs were then guided to identify sub-projects they needed the project to support. The needs were written down as proposals and submitted to the desk office (Local Fadama Desk Office) in the local government for approval. Those proposals that scaled through the process were held as Local Development Plans (LDPs) against proceeding years. According to Abang (2011), The FUGs were concerned with enterprises such as crop, agro-forestry, animal production, fisheries, agricultural processing etc and non-agricultural enterprises such as canopy renting. Sub-projects such as road construction, construction of mini-bridges, building of market stalls and building of processing units were funded by the project in Cross River State.

The state has a total of 1680 FUGs and 165 FCAs. The decision of which enterprise to operate or sub-project to be executed was left to beneficiaries concerned, the facilitators, who were contacted from Cross River Agricultural Development Project (ADP), only guided these groups in taking right decisions. The vulnerable in the state, formed several separate FUGs (Elemi, 2011). In order to ensure financial independence of beneficiaries, the project provided the following innovative features;

1. Introduction of capitalization/revolving fund scheme. Fadama user equity fund (FUEF).

a. Beneficiaries made up front contribution of $30 \%$ for needed productive assets, to get $70 \%$ matching grants from the project.

b. They were also to set aside $10 \%$ replacement value of productive assets from project year 2 . This was to ensure that the productive asset can be put in place if it develops fault or be replaced after a long time usage.

c. Saving of recovered funds in the revolving fund scheme for ownership by groups (FCAs and FUGs).

2. $50 \%$ matching grants on inputs, as against credit in the first 2 years of project life.

3. $100 \%$ matching grants for both productive assets and inputs for vulnerable groups and 155 prepayment from proceeds of activity.

4. Support to ADP, sponsored research and onfarm demonstration to deliver adequate and timely advisory and extension services.

5. Capacity building to local government council staff.

a. Institutionalization of Community-DrivenDevelopment (CDD) process by L.G.Cs.

b. Decentralization of decision making at L.G.A and community levels (Elemi, 2011).

\section{Monitoring Arrangement}

The project is executed by the Federal Ministry of Agriculture and Rural Development (FMARD),S through the National Fadama Coordination Office (NFCO). At the state level, ministry of agriculture delegates day to day operation to the state Fadama coordination office (SFCO), while at the L.G. level, day to day administration is carried out by the desk officer.

Decision making is decentralized and demand driven. Monitoring and evaluation are to be done twice (at mid-term and at project closing) (Adeniyi, 2007). 
Achievements of the project in Cross River State

Some specific operations that were completed

before the mid-term evaluation include;

i. Community owned Infrastructure:

- Federal road; 5 sets, translating to more than $11 \mathrm{~km}$.

- 2 sets of Fadama Community Association (FCA) involved culverts, translating to more than 13 culverts.

- 2 small bridges constructed.

- 39 sets of 12 - 16 number of market stalls constructed.

- 13 cold rooms constructed.

- I ware house.
- I feed mill.

ii. Advisory services and inputs supports: about 510 Fadama User Groups (FUGs) procured advisory service while 165 FUGs accessed agricultural inputs.

The following inputs were made available through the project. Agro chemicals, boreholes, fertilizers, garri processing machines, improved seed/cutting variety, knapsack sprayer, machetes/cutlasses, hoes, oil press machine, pick up truck, water pumps etc.

Community members who did not benefit directly from the project, benefited indirectly from the infrastructures in the Fadama communities.

The table below allows for comparing achievements with what was projected originally by the project.

Table 2: Fadama III achievements in Cross River State at mid-term

\begin{tabular}{|c|c|}
\hline What was Projected & Achievement \\
\hline $\begin{array}{l}75 \% \text { of Fadama households increase their } \\
\text { income by } 40 \% \text {. }\end{array}$ & $\begin{array}{l}\text { Annual mean income of beneficiaries in C.R.S } \\
\text { increased by } 41.26 \text { percent. }\end{array}$ \\
\hline $\begin{array}{l}20 \% \text { increase in yield of primary agricultural } \\
\text { products of participating households } \\
\text { (disaggregated by crops/agro-forestry, livestock } \\
\text { and fishery, etc). }\end{array}$ & $\begin{array}{l}\text { Agricultural production survey revealed } \\
\text { increase in yield of some major crops; } \\
\text { Maize }=(1.34 \%) \\
\text { Groundnut }=(0.88 \%) \\
\text { Cassava }=(24.97 \%) \\
\text { Rice } \quad=(2.63 \%) \\
\text { Yam } \quad=(0.98 \%)\end{array}$ \\
\hline $\begin{array}{l}10 \% \text { of the replacement value of assets used for } \\
\text { income generating activities of FUGs should be } \\
\text { saved annually with effect from project year } \\
\text { two.. }\end{array}$ & $\begin{array}{l}\text { About } 24 \text { FUGs saved (N723,760.80) in FUEF } \\
\text { account, this represents } 0.22 \% \text { of the total } \\
\text { value of assets. } \\
(\mathrm{N} 325,685,586.98)\end{array}$ \\
\hline $\begin{array}{l}\text { Survey at mid-term should show that atleast } \\
75 \% \text { of Fadama users are satisfied with } \\
\text { operations, maintenance and utilization of } \\
\text { community owned infrastructure and capital } \\
\text { assets. }\end{array}$ & $\begin{array}{l}\text { At mid-term, } 79 \% \text { of the participants were } \\
\text { satisfied with operations and maintenance of } \\
\text { projects, while } 81 \% \text { were satisfied with } \\
\text { utilization of community infrastructure. }\end{array}$ \\
\hline
\end{tabular}

Source: Mid-term report of Fadama III in Cross River State, Fadama coordination office.

Table 3: Summary of enterprises

\begin{tabular}{lc}
\hline Enterprise & No. of beneficiaries \\
\hline Crops & 273 \\
Fishery & 82 \\
Agro processing & 201 \\
Livestock & 270 \\
Agro forestry & 26 \\
Small community owned infrastructure & 64 \\
Total & $\mathbf{9 2 7}$
\end{tabular}

Source: Mid-term report of Fadama III in Cross River State, Fadama coordination office.

\section{Perception of Cross River State beneficiaries about Fadama III \\ Reports have shown that a good proportion of} the beneficiaries of Fadama III in Cross River State, are agricultural producers who are either directly concerned with the production of primary agricultural products or adding values to produced primary products, through processing. 
According to Ele, (2001), 'the Fadama III project sign post can be seen in many villages of the state, signifying the acceptance of the project by the farmers. The farmers have embraced the project and are ready to make it's a success'. In Angba's (2011) own view, 'despite the complaints about insufficiency of extension service delivery and several constraints, participating farmers acknowledged the positive effect of the project on their income'. Although, Fadama III is operating in several communities within each of the 18 L.G.A. in Cross River State, many potential beneficiaries do not know and some who see the sign post on road sides do not know exactly what it is all bout.

\section{Challenges of Fadama III in Cross River State}

Despite the fact that after the mid-term evaluation, CRS emerged the best performance state in the south south zone, the project is still constrained by certain factors. They include:

i. Delayed beneficiaries contribution: beneficiaries especially at the community level seem to expect the project to be free thus they refused to pay their own part of the contribution and since money was released in tranches, once a group violates, the next trench is not released. Because of this, many sub-projects have been abandoned in some communities.

ii. Inadequate funds to entertain all request by communities.

iii. Cost provided in the project document is inadequate to finance sub-projects.

iv. Sluggish retirement of funds by FCAs.

\section{CONCLUSION}

The Fadama III project has thrived in Cross River State in the face of various challenges and has high potentials for successful completion. It will do much better if it is able to improve upon its information delivery system such that the people it intends to benefit are properly sensitized on what is obtainable in the project. Create enough awareness prior to project implementation to be able to accommodate all potential beneficiaries.

\section{RECOMMENDATION}

i. Inspite of the success of Fadama III in Cross River State, beneficiary farmers still make use of back-breaking implement, efforts has to be directed towards provision of mechanized implement that will utilize little human labour.

ii. All stakeholders should make their financial contributions on time.

iii. The organization mandated to implement projects should advocate for sufficient funding from the institutions concerned.

iv. Monitoring and supervision should be intensified for better performance.

\section{REFERENCES}

Abang, S. O., 2011. Household income generation progression and sustainability of Fadama user groups (FUGs) in Cross River State, $A$ monograph pp 6, 8.

Adeniyi, A. A., 2007. Third Fadama Development Project (Fadama III). A paper presented at the Fadama III sensitization retreat, in Abuja. May 3-4, 2009, 2-3.

Agom, D. I., 2011. Analysis of the social capital formation and implementation of Fadama III in Cross River State, A monograph. 4pp.

Angba, A. O., 2011. Contribution of advisory services and input support to ADP and adaptive research to the attainment of Fadama III project development objective in Cross River State. Unpublished report. 8, 16-19.

Chudi, O., 2007. The role of the World Bank in poverty reduction and economic management: A paper presented at the Fadama III sanitization retreat in Abuja. May 3-4, 2007, 1-2.

Ele, I. E., 2011. Contribution of small scale community owned infrastructure and asset acquisition to the attainment of Fadama III. Project development objective in Cross River State: unpublished report, 3, 11.

Elemi, B. F., 2011. Community implementation manual, a working document of Fadama III project in C.R.S, 3, 9, 11, 24, 25.

Elemi, B. F., 2011. Implementation status of Fadama III in Cross River State: A monograph.1-9.

Maismari, B. A., 2007. Natural resources and conflict ,management: A paper presented at the Fadama III sensitization retreat in Abuja. May 34, 2007.

National agricultural investment plan., 2010. A Federal Government working document for agricultural programmes for 2011-2014. 13, 24-27.

Olukosi, J. O. Simonyan J. B. Omolehin R. A. and T. K. A. Atala., 2012. Productivity and technical efficiency among beneficiary farmers of second national Fadama project in Kaduna State, Nigeria: America journal of experimental agriculture. 2(1): $102-110$.

Omonona, B. T., Akinwade, R. J., Yusuf, S. A. and A. S. Oyekale., 2008. Impact of Fadama II Project on income and inequality of rural households in Nigeria: Journal of agricultural and biological science: Vol 6 No. 7. $39-54$.

Project appraisal document., 2008. National working document for Fadama III. 4, 5, 6-77. 
